Article

\title{
Gender, Land and Food Access in Ghana's Suburban Cities: A Case of the Adenta Municipality
}

\author{
Kwaku Owusu Twum ${ }^{1,2} \mathbb{D}$, Kwabena Asiama ${ }^{3, *} \mathbb{C}$, John Ayer ${ }^{4}$ and Cosmas Yaw Asante 4 \\ 1 Department of Spatial Innovation, Huts and Cities Limited, Accra GD0028407, Ghana; \\ kwaku@koa-impact.com \\ 2 Department of Project Development, Gold Coast Sustainability and Governance Institute, \\ Accra GD0889430, Ghana \\ 3 Geodetic Institute, Faculty of Civil Engineering and Geodetic Science, Leibniz University Hannover, \\ 30167 Hannover, Germany \\ 4 Department of Geomatic Engineering, Kwame Nkrumah University of Science and Technology, \\ Kumasi AK000-AK911, Ghana; jayer.soe@knust.edu.gh (J.A.); ycasante.coe@knust.edu.gh (C.Y.A.) \\ * Correspondence: asiama@gih.uni-hannover.de; Tel.: +49-(0)511-762-2406
}

Received: 21 August 2020; Accepted: 29 October 2020; Published: 31 October 2020

\begin{abstract}
The disparity in land and food access in Ghana often overlooks the possibility of an underlying gender disparity. This paper explores and interrogates the disparity between land and food access with respect to gender and the evolution of this relationship over the years as a result of the settlement expansion and urban growth within the Adenta Municipality in Ghana. Adopting a mixed pairwise approach of combining spatial analytical tools, vulnerability indexing and resilient indicators, the paper examines the levels and rates of land accessibilities within the stream of modern cities. It assesses the land market system complexities within developing economies and attempts to address the potential threats of gender-land access gaps. The paper finally assigns weights of ranks to model the phenomenon and recommends trends that can facilitate predictions and early cautionary systems for effective urban land governance in Ghana. The paper concludes that though it is noticed that women engage in power structures on a daily basis, this both benefits and burdens them, depending on their socio-cultural status and other factors in terms of access to land and food.
\end{abstract}

Keywords: gender; land tenure security; suburban competition; innovative spatial governance; food security

\section{Introduction: Land and Competitive Urban Transformation}

Though the Sustainable Development Goals (2015) and the New Urban Agenda (2016) point to the role of cities in promoting equity and sustainability, the rapid urbanisation in Ghana along with the changing land governance dynamics significantly influences these advances towards equity in household livelihoods [1-6]. Urban land demands have risen from 2\% in the 1900 to $50 \%$ in 2017 with an estimated rise to $67 \%$ by 2050 [7]. Ghana's inter-censual regional data has consequently indicated a similar trend. The Greater Accra Metropolitan Area's (GAMA) urban population overflow of outside the city of Accra (Ghana's capital, referred from hereon as Accra) shows that Accra's urban share of GAMA's overall population growth had significantly declined from $70 \%$ to $40 \%$ within 1960-1970 and 2000-2010 inter-censual periods, respectively [7]. The speed of population growth on the fringes of Accra has resulted in a surge in the competition for residential land, infrastructure and commercial centres, as well as sufficient food-causing. This has influenced the urban change pattern of Ghana's capital, which is overwhelmingly moving towards suburban districts such as Adenta. Subsequently the land distribution pattern of peri urban and suburban spaces within the capital 
region is experiencing rapid growth. These rapid changes, in terms of land use and tenure in Ghana, has gained attention in Ghana since land is an important asset for both women and men [8]. Despite the attention, although studies have recognized the essential role and functions that women play in the development and management of natural resources such as lands in Africa, their involvement in ownerships, decision-making and economic developments on space, among others, has been poorly regarded [9-11]. In fact, Dery [12] confirms that women have faced different forms of tenure insecurity, both as wives and in their relations with wider kinsmen within the social and cultural settings of Ghanaian communities. In terms of women's contribution to farming and agriculture, though women make up $49.32 \%$ out of a population of 30.42 million, $52 \%$ of the farmers are women, with women producing $72 \%$ of Ghana's food stock [13].

Though deemed significant, studies on women's access to land in suburban cities have not been adequately explored. Women's access to land in the Global South has been discussed mostly in the context of rural space. However, land management arrangements in the suburban and periurban areas have been gradually transformed from the traditional liberal market in this urbanizing district to an almost exclusive male dominated market [14-16]. These suburban areas therefore sit at the nexus of traditional practices and practices influenced by colonial masters $[17,18]$. The mix of these systems has shown to be a disadvantage to women, especially with regards to land access [10]. As a result, the rise of land tenure insecurity and discrimination is high. Furthermore, single mothers by choice within these areas are heavily depended on by their children and in some cases, other relatives [10]. Characterized by low participation in the land market, the woman's abilities are severely curtailed, with their ownership rights restricted. This also accounts for the gross marginalization and poverty in the district especially among those without formal education. Consequently, this disparity in gender within the land management sector has weakened decision making and land governance in Ghana. Despite the seemingly widening gap between men and women in land access as well as the growing challenge of food limits, women within these areas still play significant roles as bread winners as well as food providers $[10,11,19]$.

In response, this paper explores and interrogates the disparity between land and food access with respect to gender and the evolution of this relationship over the years as a result of the settlement expansion and urban growth within the Adenta Municipality. In the next section, the key concepts in this paper, land access, food access, gender and urban competition are explored, and the meeting points are identified. In the next section, the methodology adopted for the study, as well as a brief profile of the study area is given. The next section lays out the results of the study and further discusses the implications of the results shown. The fifth section concludes the paper with a summary of the findings.

\section{Land and Food Access and Gender Imbalance within a Competing Urban Space-The Nexus}

This section describes the relationship between land and food access on one hand, and gender on the other hand, within the urban setting. The section starts with an explanation of the relationship between urban competition and land access. This is followed by a description of the current dynamics of women's land rights with respect to access to land as well as food. The section concludes with a conceptual framework that depicts the land-gender-food nexus.

Cities are transforming close periurban areas into ad hoc cities, which Acheampong [20] describes as suburban areas or cities. This paper contextualizes suburban areas as suburban cities. Suburban areas are defined in contrast to central or inner-city areas, and are identified as commuting residential areas that possess a mixture of land uses [21]. Suburban areas or subcities are functions or outcomes of the overspills of the inner-city or core cities. They are "absorbers" of the population influx of typical cities. This is a phenomenon strongly seen within the Accra Metropolis (the core city) that has produced suburban cities like Adenta. 


\subsection{Urban Competition and Land Access}

Land access in most of Sub-Saharan Africa is governed by the customary system comprising well-intentioned socio-cultural rules that have evolved over centuries to grant equal access to families and individuals who are members of the land-owning group. Land access in the customary setting is akin to property rights in the western styled or statutory land administration, in that the group holds the ownership rights, with individuals holding the use rights (see below). Hence, land access in this study refers to the mechanisms through which a person can be granted these rights to use the land. In Ghana, land ownership, land rights and tenures are administered in a plural legal environment with customary laws and norms operating alongside statutes [22]. Ghana recognizes two forms of land ownership: statutory and customary [23]. $80 \%$ of the total land area in Ghana is customarily owned by clans, stools, skins ${ }^{1}$ and families. The state owns $18 \%$ while the remaining $2 \%$ is jointly owned by the state; the beneficiary interest being held by the community and the legal right being vested in the state $[24,25]$. Hence, land holding conditions are primarily determined by one's affiliation or membership to a land-owning group [26,27]. Many women in rural and urban spaces across Africa are restricted within the land market community due to the monetary barrier [4]. In fact, for the urban woman, whose economic activities are limited, this right of access to land seems to be a privilege granted by the male community [19]. In urban communities these cultural and discrimination against women is still prevalent except for those lands that are state-owned in which women may also participate in equally. This further aggravates the gender disparity to the disadvantage of women since they can only participate in the marginally owned portion of space in struggle with their majority male competitors. Urban competition is commonly influenced by population growth rates, hence making it a key indicator for evaluating the relative inequality in the distribution of any given resource whether land or food. This indicator compares the proportional variation of inequality visible in an urban area in relation to its residents and resource availability [28]. Consequently, rapid population growth without its corresponding structural developments and sufficient supply of services is conducive for urban inequalities. Thus, a spatially-balanced system through the monitoring of urban growth populations promises a better way of its management [29]. Urban population growth patterns need regular monitoring, as it is seen as a geospatial input that can be modelled for accurate assessments and predictions [30].

\subsection{Women's Land Rights and Access}

Urban population growth generally transforms the change pattern of the natural and built environment as well as the social fabric [31]. This growing change in the supply of physical resources, particularly land, is also seen in the functional and economic characteristics of the urban economy. Land is a highly valued asset across all regions in Sub-Saharan Africa, whose possession aids in wealth creation, and also improves a person's social standing and influence [32,33]. It is an essential base for food production and housing provision as well as economic undertakings which almost every human being relies (whether directly or indirectly) on it for their survival [8]. This philosophy positions the land governance literature as a multiple component system that embraces various aspects including land availability, equity, transparency and participation [19]. Within land governance, these rights are granted to all persons who are members of the group, male or female [12,34]. However, the foundation that establishes these rules relating to the ownership, use and entitlement of land narrows the inclusion of women [11]. Issues of land are complex and for it to be completely tackled, the following three conditions are to be met: the legal recognition, social recognition and enforceability by external authorities $[19,22]$. Failure to include any of these three elements renders the rights to land as incomplete. For instance, a land right that is legally recognizable but not socially recognized or

1 The stool (southern Ghana) and the skin (northern Ghana) is a body corporate (like the British crown) representing the people and headed by the chief. 
enforceable is an incomplete right. On that basis, women are seen not to enjoy equal rights to land. Rather, they have secondary rights and entitlement to the use of land and can only gain access to land through the male members of their conjugal or uterine families [11,35,36]. Such access and rights are partial, in that they can be taken away anytime that the primary rights holder of the land feels appropriate [37]. This disconnect between legal and social backgrounds is one of the main challenges that most developing countries are facing [12]. Women's access to and control over land remains a contentious issue in political, social and economic discourses. Moreover, access to and control over land is not just an issue of academic and development considerations, but a question of fundamental human rights. Therefore, everyone, especially women, require an equal and equitable opportunity without any discrimination to have rights and access to land.

\subsection{Women and Food Access}

Gender issues pertaining to women within the land market and food access have become an important subject worth exploring especially in the urban space. Food access here is viewed as one of the four pillars of food security $[38,39]$. The others being food availability, food utilization, and food stability. Food access here further comprises three aspects-physical, economic and social aspects $[38,40,41]$. Though food is usually viewed as a monetized and abundant commodity in the urban setting, with urban dwellers having a high food accessibility, some have pointed to a "rural bias" in food studies that prioritize the rural areas [42,43].

Women are largely represented in the informal suburban sector and continue to dominate a major fraction of the informal workforces in cities; particularly as urban food producers and market retailers throughout the country [44]. Discussions concerning agricultural productivity are best explained through land rights and access analysis using a social systems methodology [27]. For instance, the women outlook approach facilitated the examination of growth and poverty within the Sub-Saharan region [32,45]. It recognized that women stand at the confluence of between economic growth and human development. Women and food access concerns in Ghana show that gender disparities persist, and that food inequality is costly to Ghana's economic and social development, as it limits the realization of growth and poverty reduction objectives [19].

The situation of inequality and poverty resulting from land access restrictions is prevalent among women with little formal education [11]. Thus, it is imperative to consider the existing inequitable, unequal and unbalanced (supremacy) relationships and practices confronting the rights and privileges of women in Africa and Ghana as far as land use conditions in the urban case is concerned. Consequently, the basis for sustainable land development based on legal and social justice is underscored by the provision of a defined framework that promotes urban land access and empowerment among women. This concept also provides room for a broader view of the urban social group [32]. It is recognized that women's poverty is directly related to the inadequate economic opportunities, and access to economic resources including land ownership and inheritance, credit, low access to education and support services resulting their minimal participation in the decision-making process [9]. Many households' heads in urban areas (largely women) are vulnerable to food insecurity due to an unsustainable labor wage and support from local policies [22]. Furthermore, areas characterized by low food production for home consumption heavily depend on food imports and others. The difficulties surrounding women's experiences in urban food and land access disparity stems from the cultural and gender shifts and dynamics of urban environments, which often combine women's individualities, duties, spaces and roles [12].

\subsection{Conceptual Framework}

The future food framework of the Adenta Municipality adopted a conceptual framework which serves also as the model builder.

This framework explains that the emergence of land holding restrictions among women is a cyclical flow particularly in the urban area (Figure 1). Following the constructs of the Ghana Statistical 
Service [5] and the USAID [8] it is observed that urban growth transforms food producing areas into livable areas which comes with high economic costs. The economic functions and cost of prime lands or urban lands are still overwhelming, pushing the poor and marginalized in the society (especially women in the informal sector) out of the land market. These land access discriminations are further heightened by the cultural bias of land ownership in Ghana [46]. In effect, whilst land ownership and land rights are customarily defined and reduces women's access to land, the aforementioned conditions also cause it. Consequently, (potential) farm lands are lost to commercial areas and food supplies are left on the masses of women to confront and mitigate the resultant effect that comes with it, that is, food declines in these urban centers where informal single women are dominant.

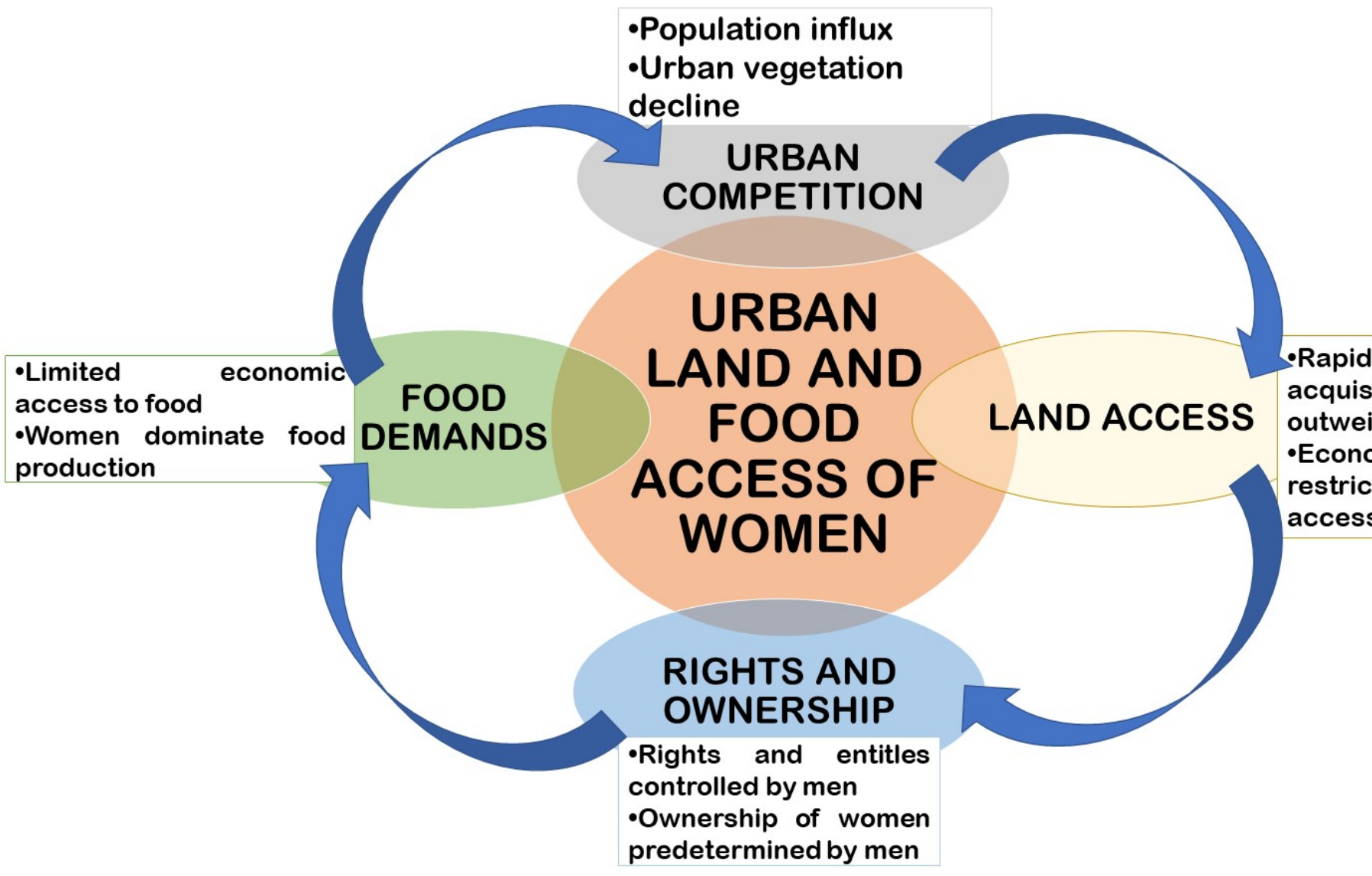

Figure 1. Conceptual framework of land-gender nexus in Ghana (author's construct).

\section{Study Area and Methodology}

This section provides an overview of the study area, with general information, as well as information relating to the study. The section further details the methodology used in the study.

\subsection{The Study Area}

$73.3 \%$ of the employed urbanites in Greater Accra fall within the informal sector. Economically speaking, the women in Adenta Municipality dominate the informal sector [47]. They are mostly involved in economic ventures such as small-scale enterprises, trading, traditional hand jobs, food vending services and the swift up-and-coming commercial food retail centers popularly known as "provision shops". This sector is currently experiencing a major surge with a lot more women are becoming interested in this sector. This earns the municipality economic revenue through taxes. The agriculture sector employs a lot of women in the municipality with $80 \%$ involved in food production [48]. Nonetheless, with the recent urban changes (i.e., the farming land conversion to 
residential areas), the food vulnerability situation in the district has escalated. Thus, the women who used to farm on these lands for commercial purposes have resorted to subsistence farming, induced labor and other means of economic survival so that they can earn a living [49].

Possibly, with the urban sprawl from the capital (Accra) and the increase in housing units, agricultural areas in the Amrahia and Ashiyie for instance, have seen very little of the purpose for which they existed. Whilst the number of residents rises unusually, land sizes drastically diminish with land uses frequently altered. This has become a great concern for the future food index of the municipality since backyard agriculture is no longer feasible. Additionally, emerging literature, observing the growing urban food decline happening in peripheral spaces surrounding cities, are quick to suggest that farmers' livelihoods and roles are complicated by the hybridized situation of land access and gender disparities [50]. Demographically, Adenta municipality is among the fastest growing urban districts in the region. With a growth rate of $2.6 \%$, and a regional growth rate of $4.4 \%$, it is among the highest in the region and therefore reflects the fast-developing nature of the municipality [51]. The swift urban change patterns and local population influx have resulted in numerous urban challenges in the district. For instance, in 2015, there was a rainfall disaster in which 12 communities with 552 households and 2208 persons were affected [48]. This does not only question the security status but also creates an alert on the complex nature of this phenomenon that needs a multidimensional approach to solve its effects through geographic information systems (GIS). Local authorities have made it a priority to develop practical steps to combat the incidence. Accordingly, food inequality and land access disparities are soaring and this can only be collectively monitored and mitigated through scientific approach using geographic information systems (GIS). Over the years, the manual and poorly monitored urban changes have been a major contributor to the poor response of the local authorities and for that matter ineffective decisions. This sets a description for a consistent and replicative methodology that can holistically advise urban policy makers for pragmatic decisions [52].

\subsection{Methodology}

The study adopted a case study methodology that embraced a joined approach of connecting nonspatial data with spatial analytical tools. The research centered on a value-based perspective known as a "rights-based approach" which espouses that access to and use of land is a basic human right issue and should be respected [5]. Thus, any barrier(s) to equal access concerning the use of land by both men and women is regarded as a breach of rights of affected members [22,53]. The adoption of the right-based approach helped to assess the level of land discrimination within the municipality. Furthermore, in order to appreciate the depth of issues, a convergent parallel mixed method approach was used with emphasis on 4 communities within the Adenta municipality. This featured critical perspectives in the research. Data were equally collected through focus group discussions (FGDs), interviews and administration of questionnaires through a purposive random sampling approach (see: [35]). In addition, satellite imagery was collected using a remote sensing approach; adopted to spatially classify areas of vulnerability based on population and municipal data. This enhanced the validity of the issues and climaxed the findings for strategic interventions [30].

Primary data from FGDs, direct interviews and questionnaires administration was complemented with satellite images and relevant secondary data obtained from divergent secondary sources, particularly, publications by government, policy think tanks and academicians (See Table 1). Additionally, some primary data were gathered from direct observations of the change of land use over time (in 1991 and 2018). Comparison was equally drawn to identify major matters that could be helpful to the selected communities. As part of the broader research design, a total sample of 60 households from the sampled areas in the municipality was estimated and interviewed. The focus of the study was to identify and interview households in urban and periurban areas in the Adenta Municipality. The Adenta Municipality is among the 151 urban districts growing within the country [7]. It was selected due to its proximity to the central business district (CBD) of Accra as well as the rapid rush for residential lands within the region. The district has similar characteristics with urban districts 
in the country [7]. Additionally, it has a unique blend of urban and periurban features. The assistance from the Adenta Planning Department was sought to give clear demarcations of the boundaries of the urban center. However, in order to effectively justify the case of food and land access disparity, purposive random sampling was used, where the zonal councils of the municipality were used as a basis for sampling for data collection. Again, respondents (being women household heads) were purposively sampled and interviewed. The selection of women was exclusively determined from local knowledge acquired from the local assembly's database. These women were selected based on their local knowledge on the topical issue and were willing to be interviewed.

Table 1. Details on respondents and sampling.

\begin{tabular}{ccc}
\hline MUNICIPAL ZONES & Sample Communities & Number of Respondents * \\
\hline KOOSE & Amrahia & 15 \\
Gbentanaa & Adenta Old Town and Housing & 15 \\
Nii Ashale & Estate & 15 \\
Sutsrunaa & Ashale Botwe & 15 \\
\hline
\end{tabular}

* Sample size for the five communities were 60 with 15 respondents for the various municipal zones ${ }^{2}$ (Source: Author's construct).

It was possible to locate the communities since it was subdivided into 4 administrative zones. Thus, the municipality was put into 4 quadrants (subzones) according to the Adenta municipal report (2016) with the center "Adenta barrier" (a local neighbourhood) serving as the epicenter for economic and social activities. The boundaries of each quadrant were also identified with the communities. The goal was to have a relational representation of households throughout the municipality. In the second stage, subcommunities within each zone were identified and randomly selected. Respondents were later selected through purposive random sampling, where respondents were interviewed per their locations.

\subsubsection{Weighting and Ranking of Data Indicators}

Considering the land management conditions and subcategorizations of the district, a set of criteria was determined to indicate the presence of gender gaps and food inequalities within the land market domain. The validation and normalization of indicator values were primarily based on other scholarly methods (see: [36,37] In effect, the study used SPSS and Microsoft Excel to standardize and normalize indicator values as shown in the following steps and formula in reference to the approach of [38].

1. To normalize all the indicators to matching units and scale, standardized values were calculated using the standard deviation formula as shown in Equation (1):

$$
\text { Standard Value } Z=\left(X_{i}-\mu\right) / \sigma
$$

where $Z=$ standardized value, $X_{i}=$ Indicator value (quantitative data collected on the land use change and access, through questionnaires and PHC data), $\mu=$ mean value and $\sigma=$ standard deviation.

2. The next step was to normalize the standardized indicator values such that the values fell within 0 to 1 in order to facilitate the weighting of the indicators. The normalized standardized value as shown in Equation (2) is defined as

$$
Y=\left(Z_{i}-a\right) /(e-a)
$$

2 Sample size was limited as a result of the time constraint factor of the research. 
where $\mathrm{Zi}$ lies between a to $\mathrm{e}, \mathrm{Z}_{\mathrm{i}}=$ standard score, $\mathrm{a}=$ minimum value, $\mathrm{e}=$ maximum value and $\mathrm{Y}$ ranges from 0 and 1 .

3. Reverse indicators, such as incidence of vulnerability and gender were further standardized using the formula $(1-Y)$ so that all values nearer or equal to 1 are those approaching food security, while those nearer zero (0) means land insecurity or within the food stress areas.

\subsubsection{Weighting and Calculating Aggregate Scores}

In this research, equal weight was assigned to each indicator based on the premise that they all possess equal significance to the land access equity of the city. Aggregate scores for each land and food dimension, defined as the Dimension Sustainability Score, were calculated using

$$
f(x)=\sum_{i=1}^{n}\left(\frac{Y i \times W i}{W i}\right)
$$

where, $\mathrm{W}=$ weighting of each indicator, $\mathrm{Y}=$ normalized value of each indicator, $\mathrm{n}=$ number of indicator and $\mathrm{i}=$ year of assessment.

Finally, the overall Urban Food and Land Access Index (UFLAI) was calculated by summing the sustainability of each dimension score year by year.

Again, equal weight (1/4) was assigned each dimension of Urban Growth (UG), Economic Access (EA), and Social Access (SA) as shown in Equation (4)

$$
\text { Urban Food and Land Access Index }(\mathrm{UFAI})=\sum_{\mathrm{i}=1}^{\mathrm{n}}\left(\frac{(\mathrm{UG} \times \mathrm{W})(\mathrm{EA} \times \mathrm{W})(\mathrm{SA} \times \mathrm{W})}{\sum \mathrm{W}}\right)
$$

\subsubsection{Using Pairwise to Simulate Land and Food Access Disparities}

The maps for the known indicators were derived from their various measurements, and were connected to the prevailing rate of land use, access and food disparity, based on the relative importance of every indicator that was evaluated. Ref. [54] categorize AHP into 3 stages: (I) Disintegration-where the urban situation is identified and structured into indicators (II) Relative judgment-this is done through pair wise comparison (III) Aggregating the priorities—calculate suitability index. Structuring of the indicators is fairly a subjective activity and somewhat relies on decision maker's expertise and experience. The indicators were therefore considered based on the importance of the field data acquired (explained above). Table 2 presents the pair-wise conditions developed in AHP for each adopted standard. Eigenvalues were used to designate the relative importance weight of each indicator according to the parameters of [55].

\begin{tabular}{|c|c|c|c|c|}
\hline & \multicolumn{4}{|c|}{ Pairwise Comparison-Criteria Comparison Matrix (C) } \\
\hline & Urban Growth & Economic Access & Social Access & Total \\
\hline Urban Growth & 1.000 & 0.140 & 3.000 & 4.140 \\
\hline Economic Access & 7.000 & 1.000 & 5.000 & 13.000 \\
\hline Social Access & 0.330 & 0.140 & 1.000 & 1.470 \\
\hline Sum columns & 8.330 & 1.280 & 9.000 & \\
\hline Variables & \multicolumn{4}{|c|}{ Description } \\
\hline 1 & \multicolumn{4}{|c|}{ Equal importance } \\
\hline 3 & \multicolumn{4}{|c|}{ Moderate importance } \\
\hline 5 & \multicolumn{4}{|c|}{ Strong importance } \\
\hline 7 & \multicolumn{4}{|c|}{ Very strong importance } \\
\hline 9 & \multicolumn{4}{|c|}{ Extreme importance } \\
\hline $2,4,6,8$ & \multicolumn{4}{|c|}{ Intermediate values between adjacent scale values } \\
\hline
\end{tabular}

Table 2. Pairwise conditions. 


\subsection{The Adoption of Spatial Frameworks and Multiple Evaluation Methods}

More than millions of urban inhabitants currently face land and food challenges in Ghana precisely within its urban cities like Adenta. This has largely been associated with the threatened residual income size, food expenditure and the deficient capacity to produce food arising from the land access restriction of the urban majority [46]. Therefore, the processes involved in how land is acquired, how it is distributed and the actors involved have a direct bearing on the affordability and access to food [50]. This chain of variables could be well appreciated if closely related to space and analyzed using suitable spatial models and techniques. Subsequently, the ability to understand and monitor the change systems of urban areas and evaluate its patterns is a right direction to address land and food insecurities [56]. Attempts have been made by various national and international bodies to face urban land issues and food security the technological way. Like Hagai, [56], this research follows a pattern of coupling the diagnoses of land access disparities and their relationships with food systems and women in the district using GIS. These dynamics have been overlooked in many studies of urban land and food security, but recently even international bodies including World Bank, RUAF and FAO are all moving towards the direction of multi-evaluation of gender, land access and food declines. Against this background, this research has modelled the process of food and land security assessment particularly among women using GIS tools, based on data representations on urban transformation and land rights indicators. These were in the form of GIS layers and were well integrated using the multi-evaluation model approach [29]. Further, the application of GIS modelling approaches is relatively faster and convenient than statistical manual methods, where components of gender, land and food systems can be analyzed. Information ought to be executed readily, so as to facilitate evidence-based understanding of food imbalances, thereby guiding city authorities in decision making with regard to designing equitable methods of food frameworks and urban models for effective local decisions.

\section{Results and Discussion}

This section sets the paradigm of underscoring the multidimensional nature of land tenure security, gender disparity and the preposition of land use governance within the suburban cities of Ghana. From a baseline analysis of the Adenta municipality, the indicators were analyzed and placed in perspective to align critically with the system of measuring the land access disparity in the country. The section presents and discusses the results of the study from the social, economic and spatial aspects of land and food access as shown in Section 2.

\subsection{Urban Competition and Land in Adenta Municipality}

One of the key urban indicators is the population distribution and spatial emphasis of the municipality. This phenomenon monitors and tracks urban spills, population increases and deficiencies of an area. It further plays a key role in monitoring the rate of access and use of land. The population of the municipality reckons to be increasing at a significant rate with a sporadic urban growth of 4.87 currently. This growth correlates to the sporadic regional urban growth of 4.4 (Figure 2). This calls for pragmatic attention to be given to urban land monitoring and food inequalities within the municipality. The phenomenon of urban competition and land access restriction has contributed to a gender gap within the municipality. The study explored, according to the literature review, indicators to check the level of access. The urban land and food systems indicators used to assess inequalities were urban growth, economic access and social access. These parameters were adopted from [38] as a metric system for evaluating the food and land access situation of Adenta municipality.

Likewise, the urban growth of the municipality is projected to rise in the next 5 to 10 years and this is a determinant for land access and food disparity in the city. However, the results gathered revealed that the rate of urbanization in the Accra city (1.97\%, [57]) gradually reduces, whereas that of the municipality is increasing rapidly at an annual growth rate of $4.87 \%$ per annum. This is as a result of the presence of sprawl and urban migration from the "choking" city center to the "free periurban" 
areas. Adenta municipality is one of the key population absorbers from the Accra central city of the Greater Accra region. This urban character has positioned the Adenta municipality in a critical view that requires a consistent approach to salvage its associated urban problems particularly towards land and food inequalities. For instance, the municipality records various levels of poverty, informality and vulnerabilities among women. In order to understand this change, the internal system of the municipality was considered. These internal systems include urban population growth, congestion and others which have led to continuous struggle for occupational and residential land in the subcity.

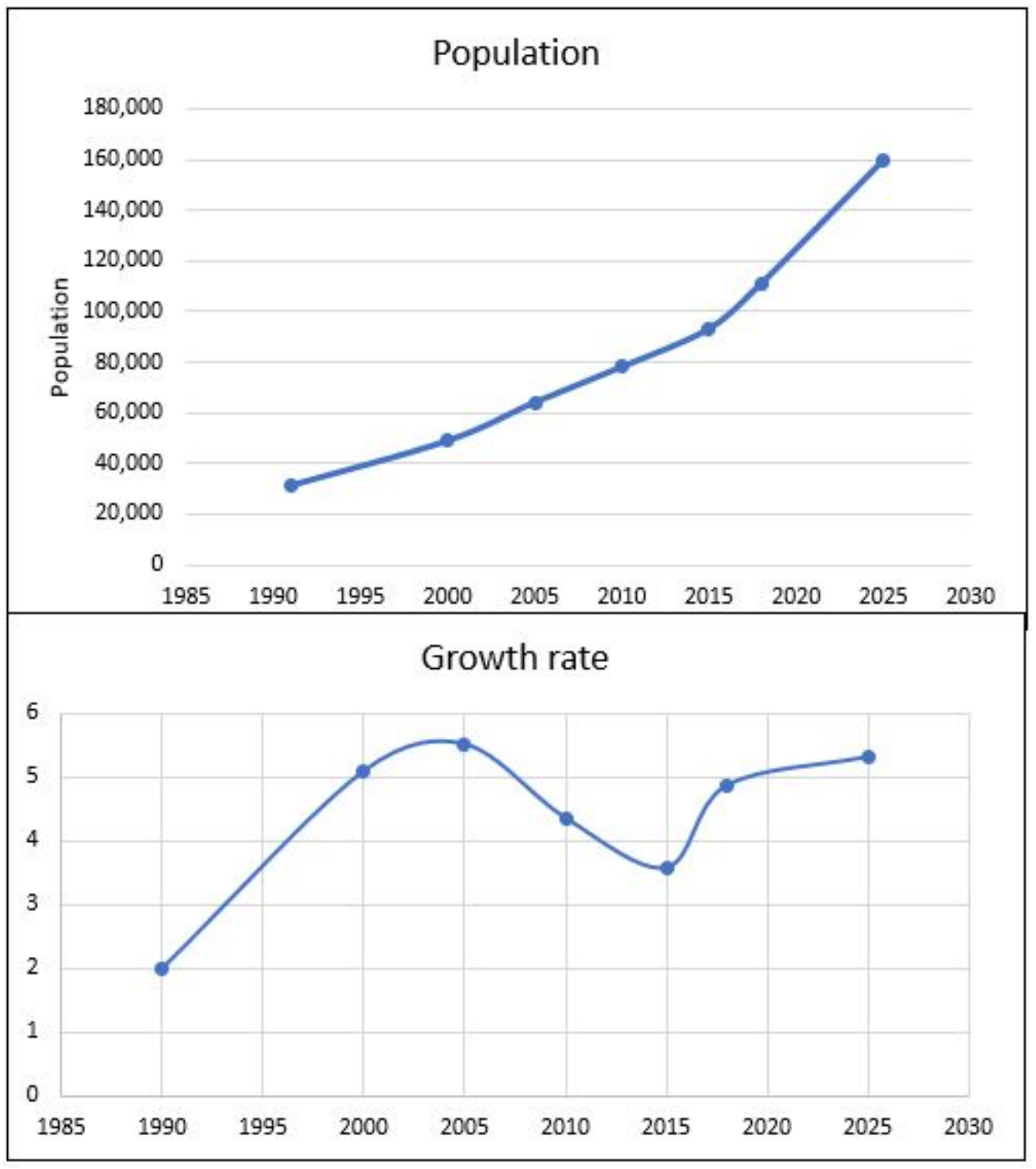

Figure 2. Population distribution of Adenta municipality from 1991 to 2025.

\subsection{Urban Sprawl, Vegetation Loss and Food Declines}

Africa continues to transition into an urban continent over the years and the rate of urban growth translates into the decline of agricultural lands for food. In Figure 3, it is identified that many countries including Nigeria, Cameroon, Benin and Togo (boundary nations of Ghana) have similar characteristics with the rate of change in their agricultural land loss. The rise is evidently noted in the early 1990s and 2000s and the trend has remained the same since then. However, projections from the Ghana Statistical Service [7] estimates that these rates could double in the next 10 years. Hence, the rapid change in 
urbanization with its direct impact on land use and access is a phenomenon not only in Ghana but throughout the continent.

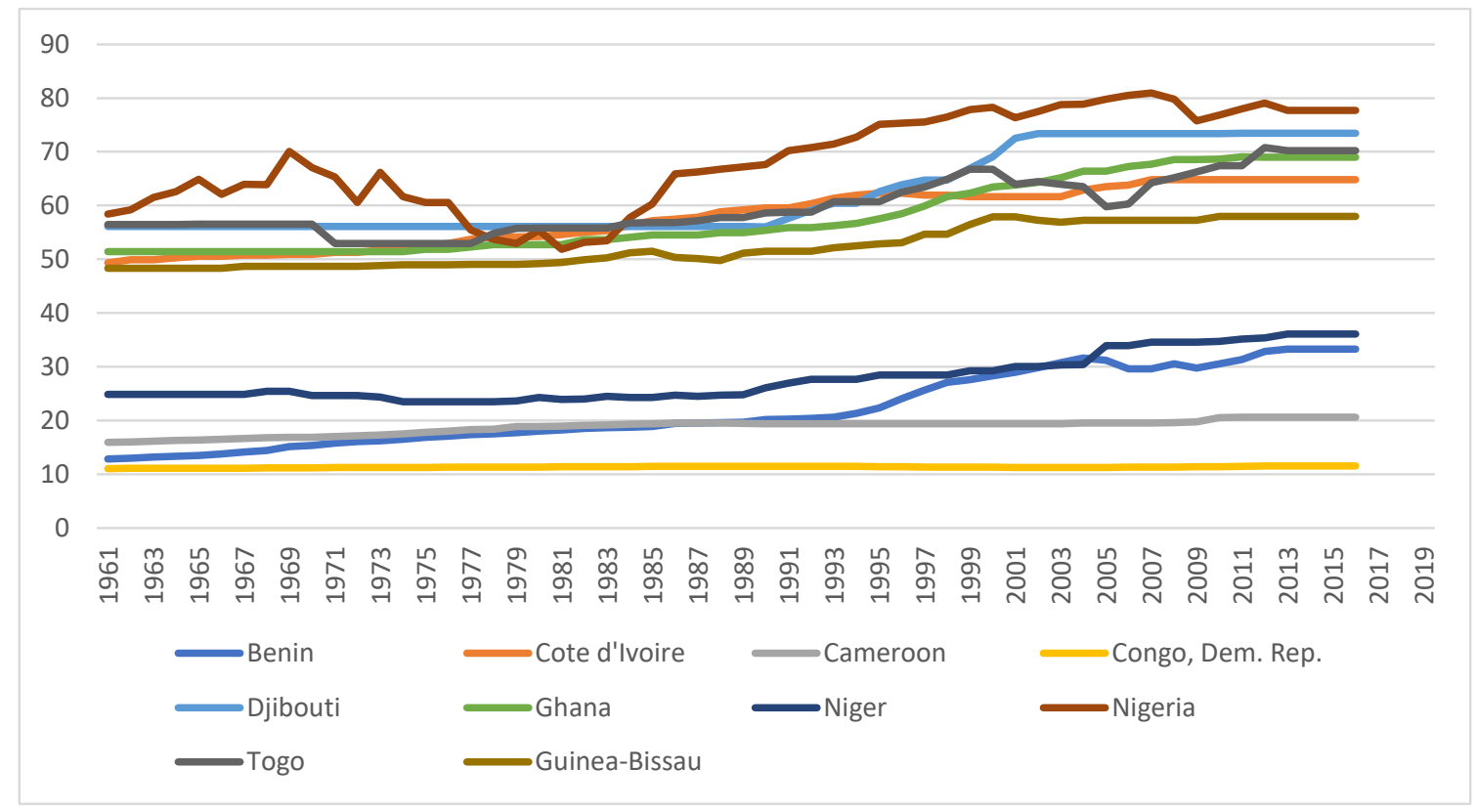

Figure 3. National distribution of agricultural land loss in selected countries in Africa. Source: World Bank Database, FAO Database, (2020).

Similarly, the struggle for lands for residential and commercial use particularly in African urban and suburban cities is pronounced. Population growth and urban change which causes the sprawl of cities is a major contributor towards urban food loss [4]. For instance, rapid population growth in Ghana is reflected in the rapid expansion of land cover class in settlements [45]. Urban areas grew from $1460 \mathrm{sq} \mathrm{km}$ in 1975 to $2560 \mathrm{sq} \mathrm{km}$ in 2000 and $3830 \mathrm{sq} \mathrm{km}$ in 2013, a rise of 161\% over 38 years [7]. Among these regions, the greater Accra (shown in Figure 3) recorded high rates of change in agricultural or vegetational land loss. This shows that the more urbanized districts in this region, the more food availability and access is limited. There is the need for a cross-regional and cross-national collaboration towards sustainable land management policies that includes gender indices.

According to Table 3, the population change of the municipality was analyzed with respect to its zones which displays the internal change and distribution pattern. As indicated above, despite the gross change of population rise within the municipality, its level and rate of change vary from location to location. In other words, the population and growth pattern within the municipality is unevenly distributed (Figure 4). This is particularly due to the functional differences and socio-economic evolutions that characterize each zone (Figure 5). The physical concentration and socio-economic limitations of cities constantly affects the access to land and food systems in the municipality.

Table 3. Population distribution of Adenta municipality represented in their zones.

\begin{tabular}{ccccccc}
\hline Municipal Zones & $\mathbf{1 9 9 1}$ & $\mathbf{2 0 0 0}$ & $\mathbf{2 0 0 5}$ & $\mathbf{2 0 1 0}$ & $\mathbf{2 0 1 5}$ & $\mathbf{2 0 1 8}$ \\
\hline Koose & 2686 & 4282 & 5511 & 6995 & 27,436 & 33,631 \\
Gbentanaa & 9274 & 14,432 & 18,974 & 23,009 & 8341 & 9938 \\
Nii Ashale & 9898 & 15,414 & 20,198 & 24,535 & 29,256 & 34,852 \\
Sutsurunaa & 9499 & 14,942 & 19,511 & 23,676 & 28,231 & 32,684 \\
Total & 31,357 & 49,070 & 64,194 & 78,215 & 93,264 & 111,105 \\
\hline
\end{tabular}

Source: AdMA Medium Term Development Report, (2008 to 2018). 


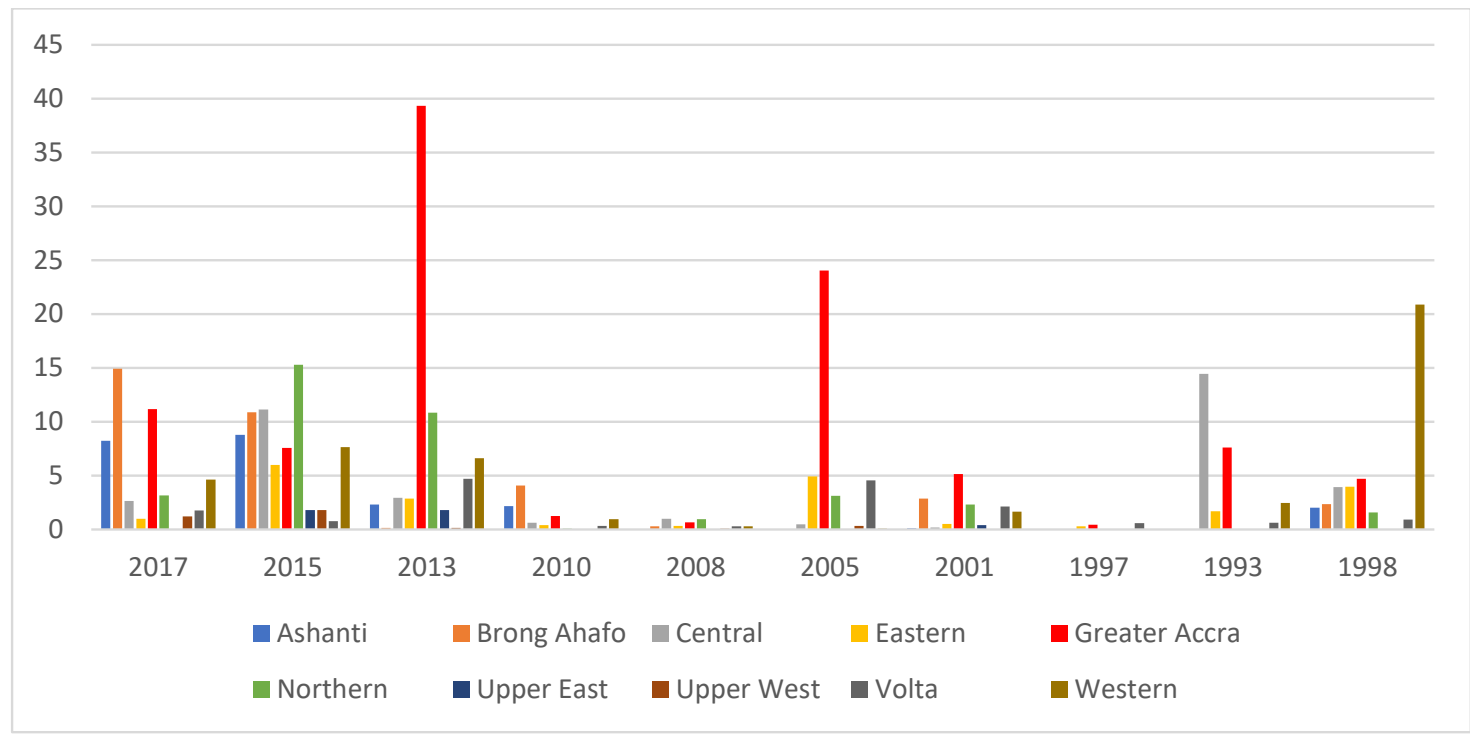

Figure 4. Regional distribution of urban agricultural land loss due to urbanization. Source: Agricultural Stress Index, FAO (2017).

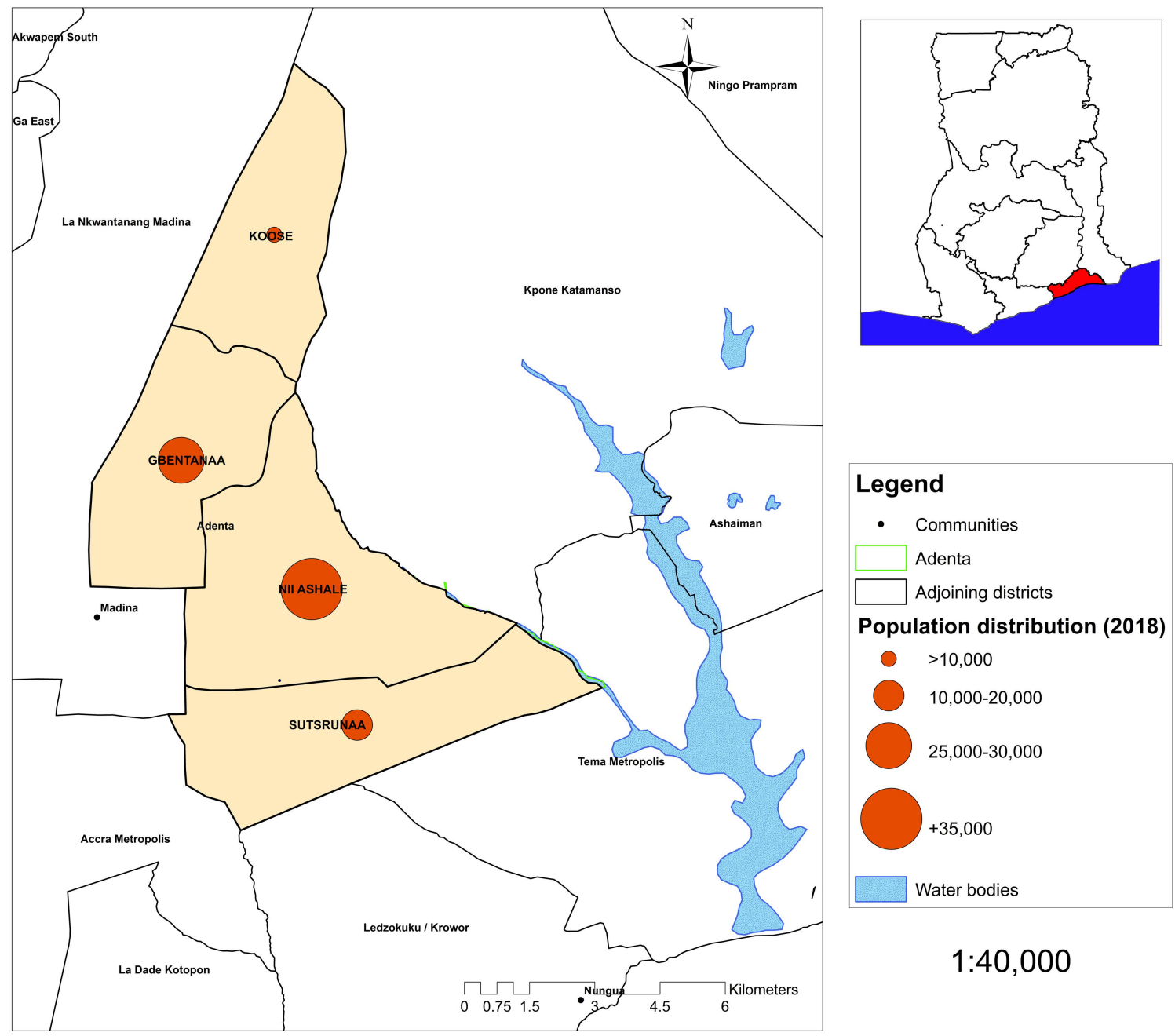

Figure 5. Population distribution of Adenta municipality in 2018 shown in zones (author's construct). 


\subsection{Economic Access}

As a component of land and food access, economic access of the citizenry, particularly women, is an essential component for the development of every nation. The economic component of land and food access disparity discussed considers the income levels, land and food expenses in the municipality. Although the Adenta municipality is perceived as a middle-class city, the terrain has expressively transformed due to urban changes. Currently, the informal sector is catching up with almost $40 \%$ of the working class moving into the informal sector. Again, a significant portion (12.7\%) of the population (mostly women) do not work and therefore depend on their working relatives for food access. This represents a typical characteristic of urban sprawl, as the city keeps expanding. In effect, the urban economy of the Adenta municipality has been polarized, with an average monthly income of Ghc 1200 (USD 220) $^{3}$. Additionally, the economic access to food has become a great concern to both the formal and informal income groups. For instance, over $50 \%$ of the population spend close to $40 \%$ of their net income on food which is worrying. This situation is worsened in the case of low-income earners.

Another aspect of the economic access was the eating times of the urban dwellers. According to the definition for food security, one must be able to afford food in their required nutritional proportion at all times. The situation is somewhat different in the municipality. Almost 50\% indicated that they only eat twice a day; whilst close to $15 \%$ eat three times a day. It was recorded that some even eat once a day. This implies that despite the income levels and social status of the urban residents, low food security is evident. In fact, it must be noted that this indicates traces of urban marginalization, inequality and poverty. Conversely, a major reason for their eating times was due to high costs of food for the majority and the high rental values on the part of others. Figure 6 indicates the notable areas that this urban phenomenon occurred.

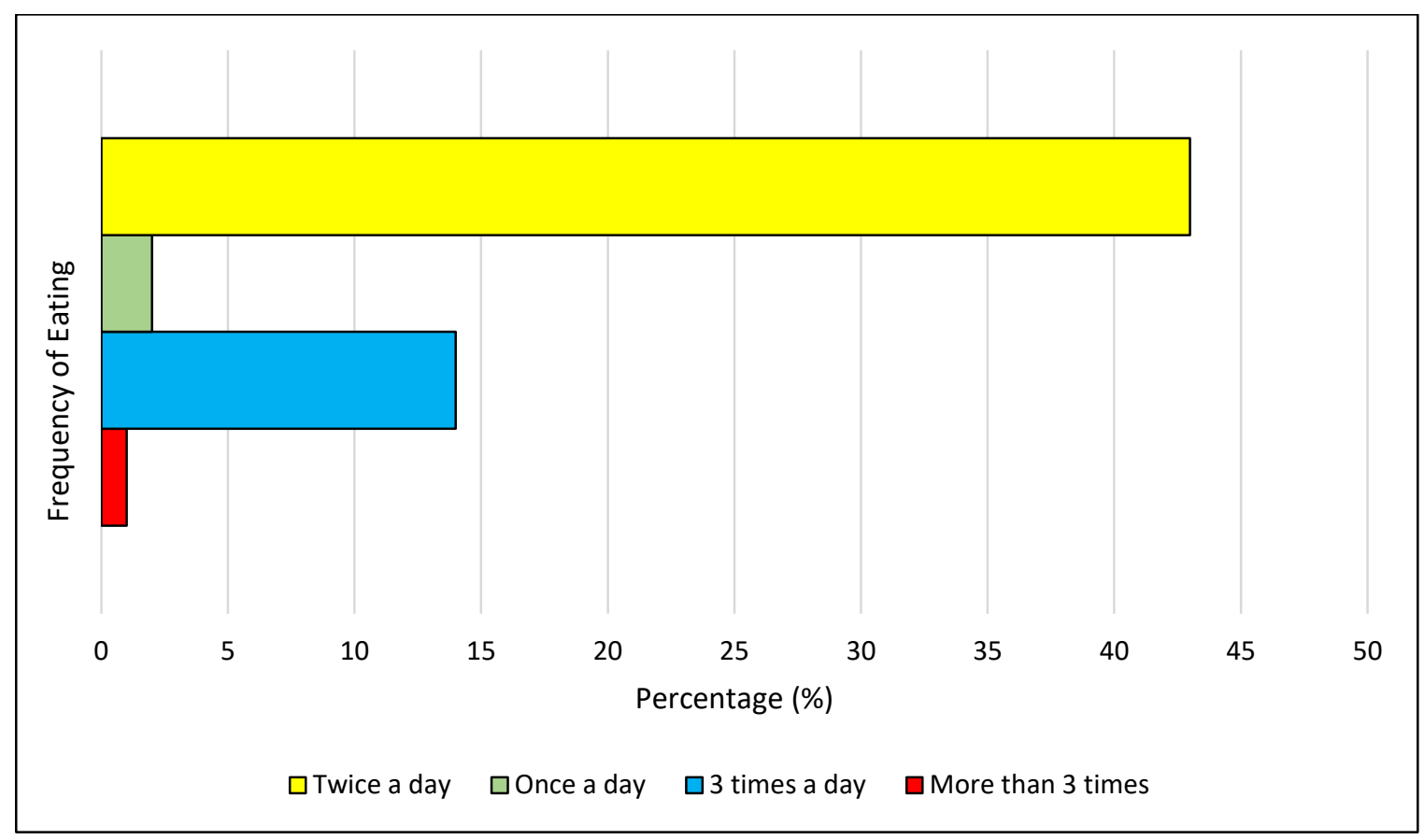

Figure 6. Frequency of eating for people in Adenta municipality.

The nature of land and food access disparities breed sensitive areas of vulnerability and insecurity patterns that emerge in the life of the urban woman. Darfour and Rosentrater [57], indicate that about

3 Exchange rate used $\$ 1=$ Ghc 5.5 . 
2 million women are prone to food insecurities and are normally characterized as urban vulnerable groups as a result. This suggests an unanticipated natural or human-induced shock that can greatly affect the chain of food consumption in the district. From Figure 7, it can be observed that although traces of low access cuts across the municipality, urban residents in Koose and Gbentanaa record severe vulnerabilities with low access to food. This is largely due to the rate of urbanization and inability to access land for economic gains. This is because many $(80 \%)$ of these female occupants are farmers and farm workers who depend on their farms for survival. Unfortunately, all these areas keep experiencing conversions from its agricultural areas into commercial and residential land uses.

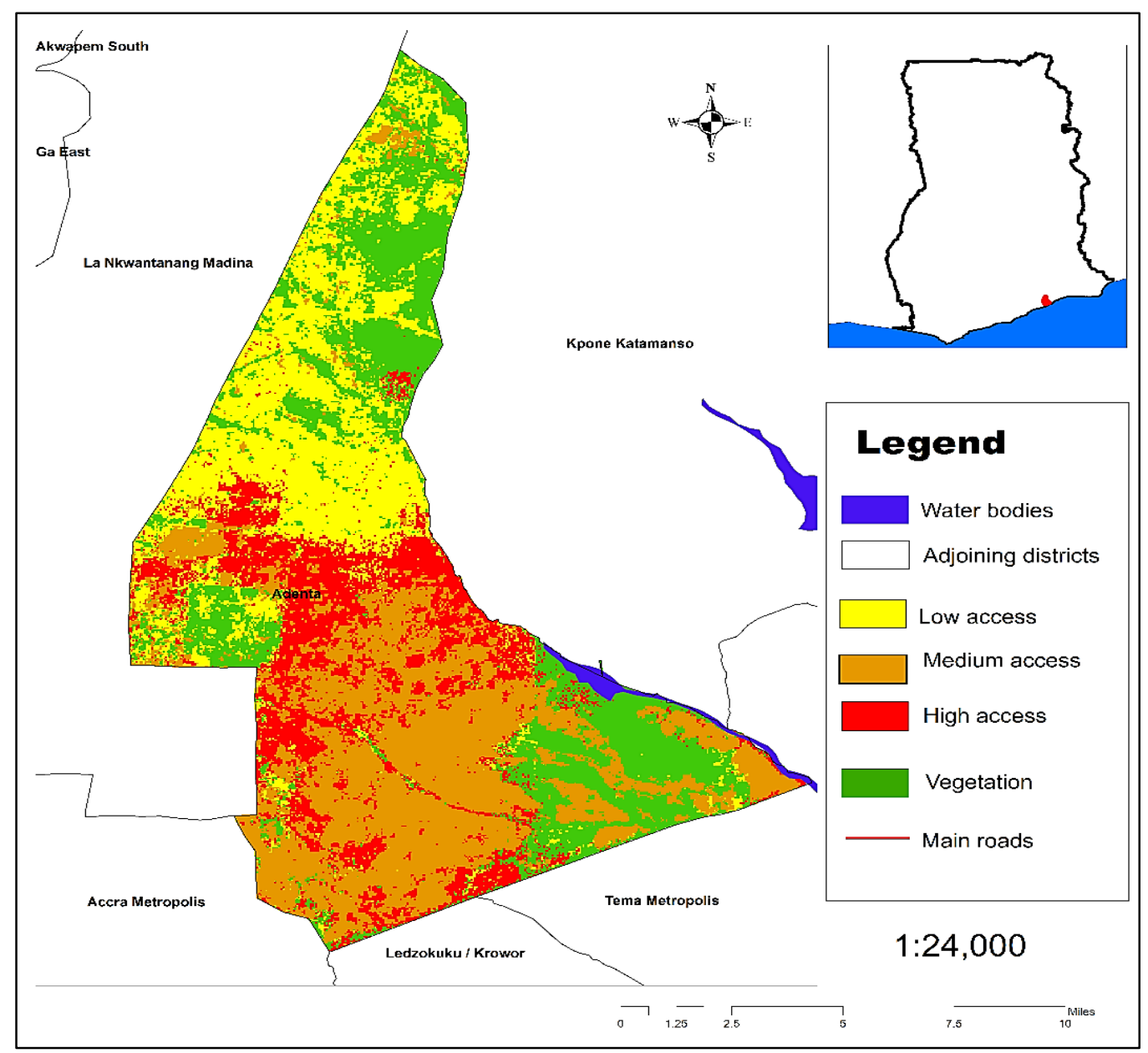

Figure 7. Economic access to food shown in zones (author's construct).

Again, food is arguably available in the country but it is not accessible to all sections of the population, especially the marginalized women and children in the society [57,58]. In Ghana, 1.2 million people suffer acute food insecurity and a further 2.07 million are vulnerable to poor diets in the country [21]. Incidentally, food insecurities are traced to poor land access conditions popular within rural and urban areas that are economically weak. Subsequently for urban areas, the informal communities are characterized by significantly less food production for home consumption since the major household heads are women who heavily depend on food imports due to the land access restrictions. Notably, 73.3\% of the employed urban inhabitants in Greater Accra fall within the informal sector of employment with over $55 \%$ being women. It is therefore expensive to afford food at all times with the right nutrients by these urbanites since most resort to street foods or already-processed food. According to the food prices as at February, 2019 for instance, a $25 \mathrm{~kg}$ bag of maize was sold at Ghc 146.26 (EUR 25.89) in Accra with a 2.49\% increment whilst it was sold at Ghc 115 (EUR 27.44) in Bawku. Likewise, a bag of local rice gained a 1.24\% increment from Ghe 326.71 (EUR 57.83) to Ghe 400 
(EUR 70.80) in Accra whilst it was recorded at Ghc274 (EUR 48.50) at Tamale [59]. This clearly shows that due to the fast rate of urbanization and human concentration in the municipality, food is becoming more and more expensive as food demand keeps soaring whilst land keeps diminishing. Moreover, the lack of space and unavailability of food largely accounts for this shortage within these sub cities.

\subsection{Social Access}

Figure 8 indicates the social dimension of the disparities of women's access to food and land in the Adenta municipality. With an increasing growth of women in the informal sector, the economic groups of the urban food system confirm that despite the variations of income, over $50 \%$ of net income is spent on food. It can be realized that despite the presence of land and food, the link to access and utilization is broken. In fact, it is observed that the poor and marginalized who represent the low-income groups stand rather higher risks of inadequate access to food.

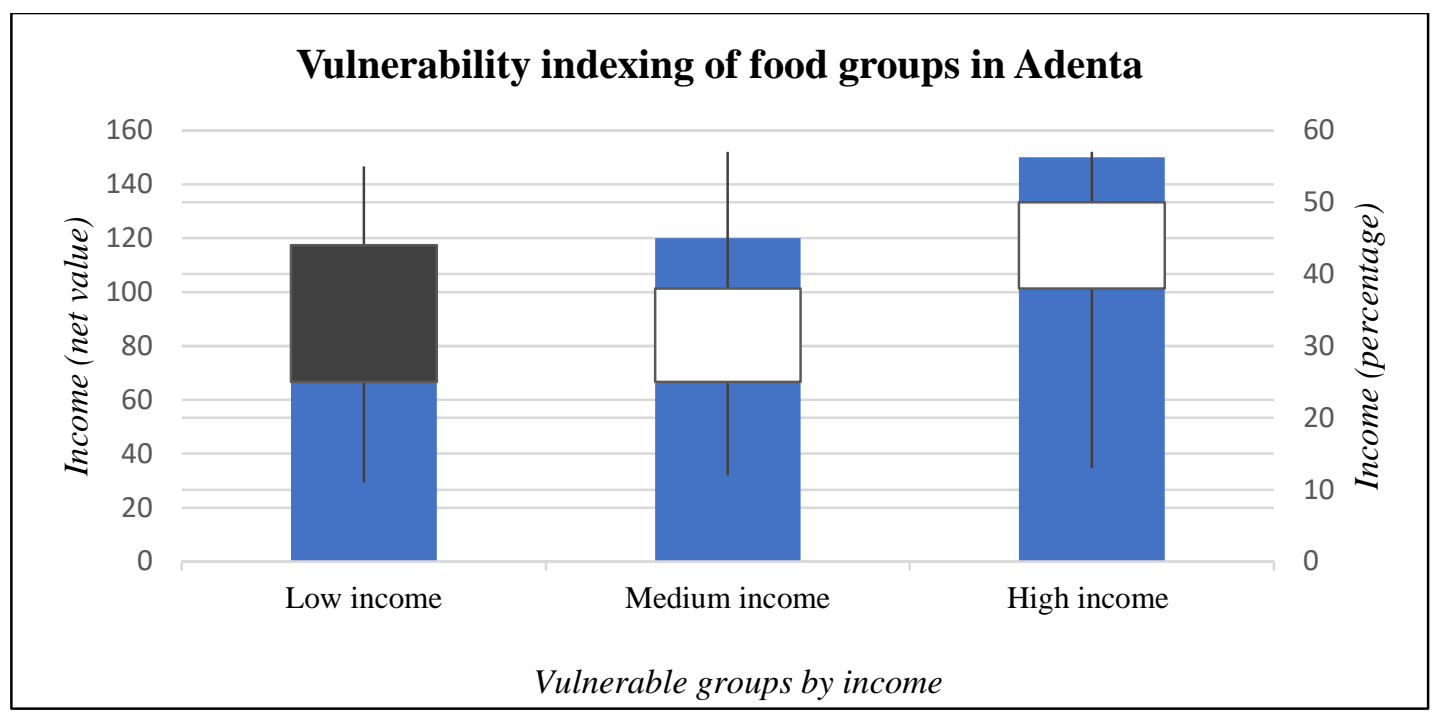

Figure 8. Vulnerability indexing of food groups in Adenta municipality (Source: Adenta Municipality medium term report, 2017).

The women of Adenta Municipality progressively dominate the informal sector [59]. Most household heads in the Adenta Municipality are women, particularly as a result of the high rate of single parenthood. Hence, they constitute a majority of household leaders who ensure household food security. This leaves a heavy burden of urban survival on the women and children despite all developments to make their lives better in the municipality [60]. In addition, most resort to informal job opportunities particularly in the food sector, an area that seems to be of great priority to the survival index of the Adenta Municipality and Ghana.

According to AdMA [48] the agriculture sector employs a lot of women in the municipality with $80 \%$ involved in food production (shown in Figure 9). Nonetheless, with the recent urban changes (i.e., the farming land conversion to residential areas), the food vulnerability situation in the district has escalated. Thus, the women who used to farm on these lands for commercial purposes have resorted to subsistence farming, induced labor and other means of survival so that they can earn a living. The women lack the necessary support such as access to and control over land which remains one of the fundamental sources of power defining women's status, identity and opportunity in many communities in the Adenta municipality. 


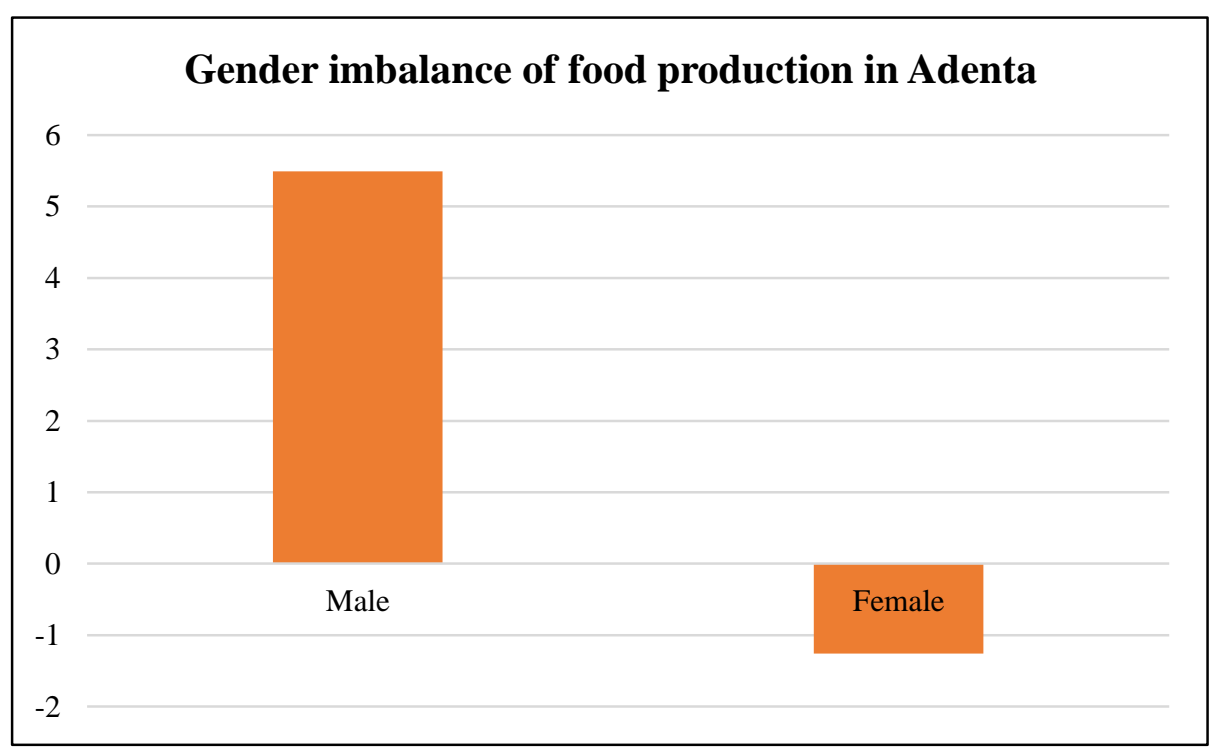

Figure 9. Gender imbalance of food groups in Adenta municipality [48].

\subsection{The Role of Sustainability Food Frameworks in Urban and Suburban Districts}

Recent research in the area of urban and regional sustainable food system community has shown that various strategies and plans devised by city authorities particularly in the Global North, but not in the Global South. For instance, FAO [61] points out that over 100 cities globally are setting examples for the first time in global urban food frameworks. As a result, the built-up cities are taking the lead in food strategies and seeking steps to reimagine food as an urban subsystem whose sustainability is firmly knitted with that of all other basic urban systems such as mobility, housing, utilities and waste management. The concept of livable cities clinches on sustainable food systems which profess a healthy, equal and ecologically balanced urban space [50]. This is progressively receiving recognition. As a matter of local policy, it is becoming a major responsibility for national and international government organizations to pursue sustainable food frameworks [3]. Accordingly, the urban food phase has evolved from the agrarian-dependent perspective to a complex modern theory. The projections of suburban cities and food security are not only concerned with its generation, but the reality of modern socio-ecological functions expressed by urban societies such as Adenta Municipality. A significant solution to these difficulties may be to develop a stronger analytical linkage between a series of methodologies and sources of information that have the potential to contribute to food and land insecurity assessment coupled with vulnerability monitoring. In this regard, the recognition and implementation of a multifunctional framework in land management influences its sustainable spatial use [62]. The need for a sustainable urban food and land framework is therefore, indispensable.

The major challenge has been the lack of a monitoring system as a result of the inconsistent and essential data. Addressing the unreliable, analogous and relevant data combined with the fragile information base therefore represents a prime priority and precondition for future work. Addressing this challenge, the strategy of a sustainable urban food system consisting of two steps is recommended: first, discovering and prioritizing urban data, and monitoring information needs in the local communities is essential; secondly, efforts to determine multiple, inventive and efficient ways of systematically collecting and analyzing this data can facilitate decision-making [63]. Hence, depictions of these urban areas derived from satellite data principally promises the most congruent measure of defining surface properties [61]. This can help set a rudimentary step of assessing the urban land and food patterns of the district and ensure a quantitative description of the urban space for predictions and framework designs. Frameworks assist city authorities and other stakeholders to better comprehend issues, distinguish problems, prioritize tasks or programs and facilitate policies. It also guides policy analysis and contributes to effective policy assessments. For instance, food systems and vulnerability 
analysis among others support the identification and targeting of urban classes such as women to help in easy intervention and implementation of plans [64]. Geospatial analysis provides a socio-spatial perspective to examine many urban food issues including food accessibility and urban agriculture land uses [55]. It should be noted that sustainable food and land frameworks are not intended to be the most comprehensive structure, rather, the most appropriate for contemporary food analysis, considering suburban change complexities [58].

\subsection{The Complex Nature of the Land and Food Disparity}

The Adenta Municipality experiences multiple dimensions of gender disparity as far as food and land access is concerned. From Table 2, the pairwise comparison tool was adopted as parameters for identifying the food and land access disparities within the municipality. The speed of population growth on the fringes of Accra has resulted in an equivalent surge in demand for land to reside, infrastructure and commercial centers to trade, as well as food to satisfy-causing a profound swelling of the suburban populace. This has successively influenced the urban growth pattern of Ghana's capital, which is overwhelmingly moving towards previously periurban districts (such as Adenta), that surround the Accra city. In effect, the express changes and condensations have altered the physical and socio-economic features of thes suburban communities [4,65]. A key component of this change is the urban food dynamics that follow. For instance, before the recent redemarcation of districts, the official boundaries of Accra covered only 300 sq. km, or $7.4 \%$ of Greater Accra region's total land area, with the rest dominated by agriculture [7]. However, due to the limited capacity to contain the rapidly growing urban population and economic activities, Accra's massive spill over into periurban settlements have drastically reduced their vegetative presence and affected farmlands. For instance, from 10, it is realized that the urban growth dimension which represented the physical composition of the municipality is grossly distributed but more evident in the zonal areas of Gbentanaa and Nii Ashale. This is because the city center is within the suburban region of the Accra city and it keeps absorbing the population influx of the main cities of Accra.

Again, the economic indicator represented the gross decline of the income levels of people particularly women. Lands and rental values in the municipality keep escalating at a competitive rate. This situation prices out individuals in the society who cannot afford habitable lands. In fact, most of these sections of the urban space are made up of women. It is observed from Figures 10 and 11 that people residing in the municipality have limited economic access to land especially those in Koose and Gbentanaa.

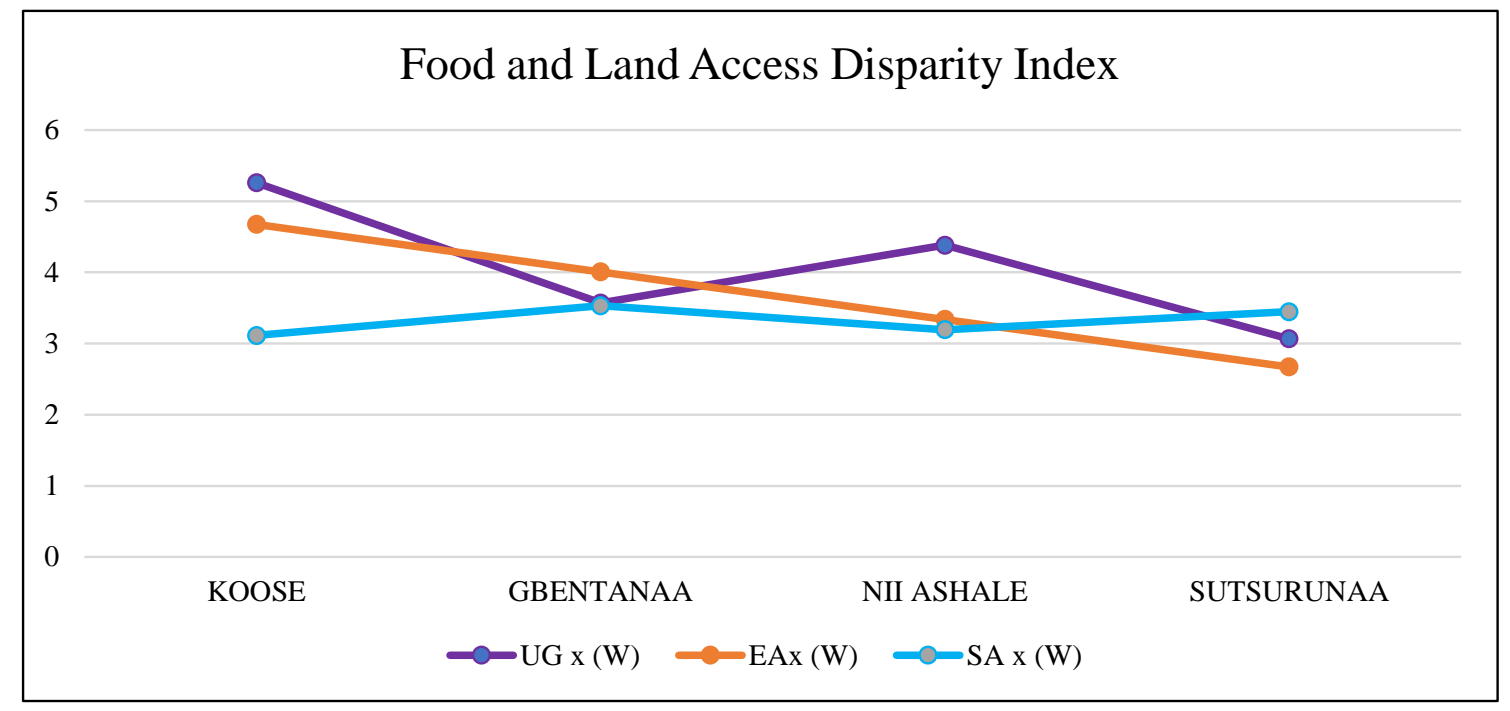

Figure 10. Food and land access disorder index in the municipality (source: field survey, 2019). 


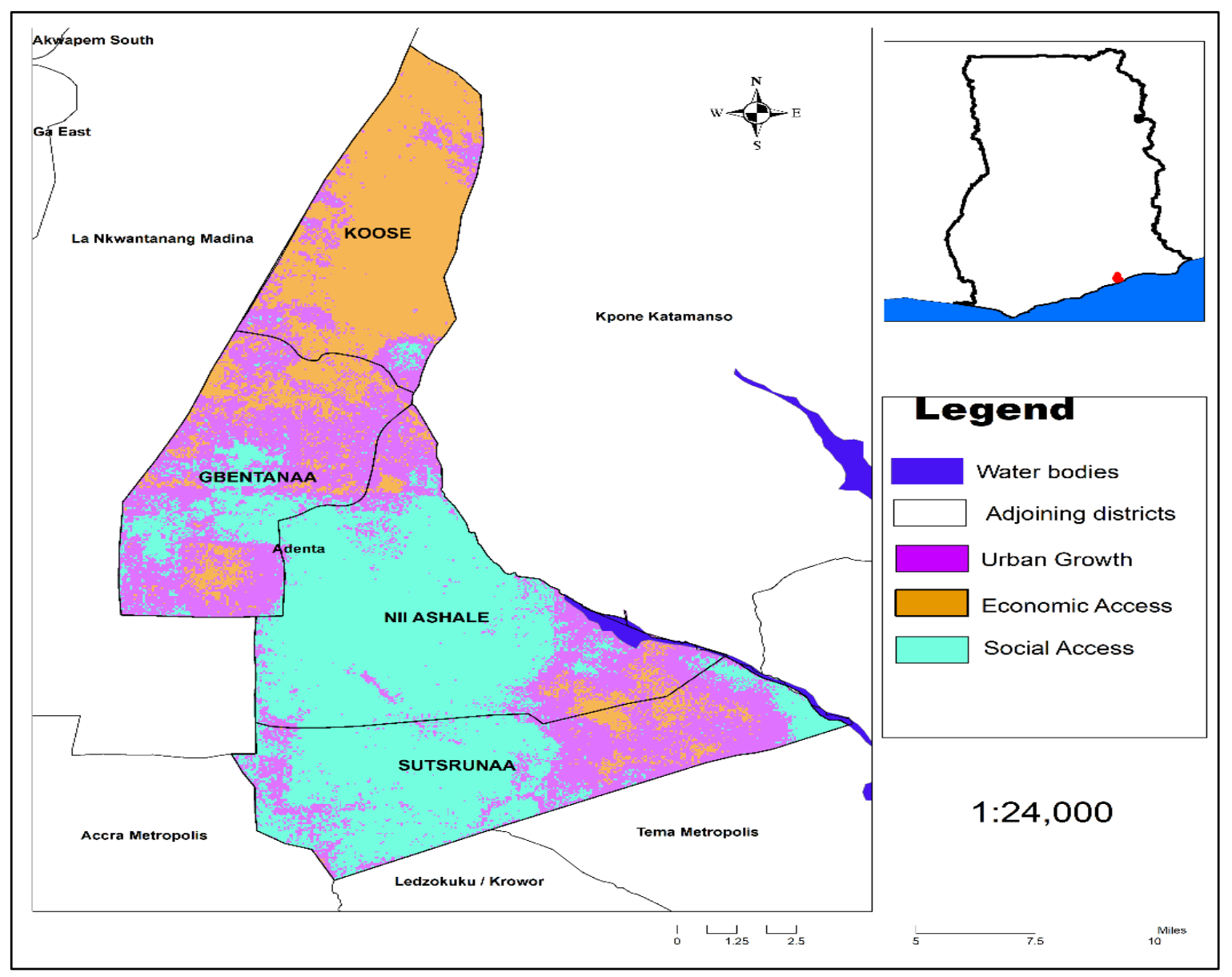

Figure 11. Food and land access disparity index in the municipality (source: field survey, 2019).

Furthermore, the risk of food is directly associated with forms of land vulnerability, and at some point, poverty. Therefore, the social dimension of land and food access disorder was predominantly associated with urban inequality, gender discrimination in buying land for occupational and commercial purposes such as farming and trading. The Adenta municipality was previously known to be a middle-income level district upon its creation. However, the change pattern of its urban domain has embraced various levels of income groups and therefore reflects different forms of food risks, vulnerability and inequality. In fact, the rate of urbanization is rapidly altering the so-called food and land equity state of the country and if the steps of multidiagnostics and criteria-based decision-making are not embraced in addition with the right technology of GIS; the country could be in a food crisis in the coming years, with women being the most significantly affected urban actors. Therefore, it is necessary for steps to be taken to reinforce the land and food subsector for pragmatic decisions to be made now and in future. These indicators could serve as strategic benchmarks for the municipal assembly to adequately track the rates and levels of urban change to facilitate decision making.

\subsection{Land and Food System Dynamics in the Adenta Sub-City}

Food and land access are increasingly becoming urban development issues in urban and suburban areas [61] for which the concept of urban land and food systems has gained considerable popularity from local and inter-regional levels [21,23]. The food systems of the growing sub city are prone to a range of socioeconomic and agro-climatic shocks and this could further aggravate if food systems measurements are trivially recognized. Suburban cities like Adenta in the Greater Accra region will always be dependent on cross food systems; that is, they will continue to outsource food, from further locations and global food chains as well as from nearby rural, periurban and urban producers. Although 
its urban residents are entitled to various food options such as processed foods, street foods, fresh foods, imports and others, its over dependence on global food supply and systems has increased vulnerabilities and risk with a rippling effect on local economies. The narrative surrounding its constituents contributes to the dynamic nature of land and food systems in the municipality, and has of late affected the social and economic landscape (as indicated in Figure 8 above). For example, compared to rural food systems in Ghana, suburban food systems are having more stress index in the urban communities than the rural. Particularly within the economic and social dimensions, many urban groups (especially women) within the country are at risk when it comes to food. For instance, the findings confirmed that about $50 \%$ of the urban groups were willing to give up their organic foods to go for genetically modified (GM) foods. Again, over $20 \%$ were willing to patronize genetically modified foods, whilst almost 30\% greatly considered it (Figure 12). Many attributed this condition to their economic standings: "I feed 7 children every day; we sometimes eat once a day, because we cannot afford all food ingredients" (Street hawker and single mother, Adenta Commandos). This alarming finding indicates that despite local repulsion for GM foods, there is the likelihood on the rush for GM foods over organic foods due to economic limitations.

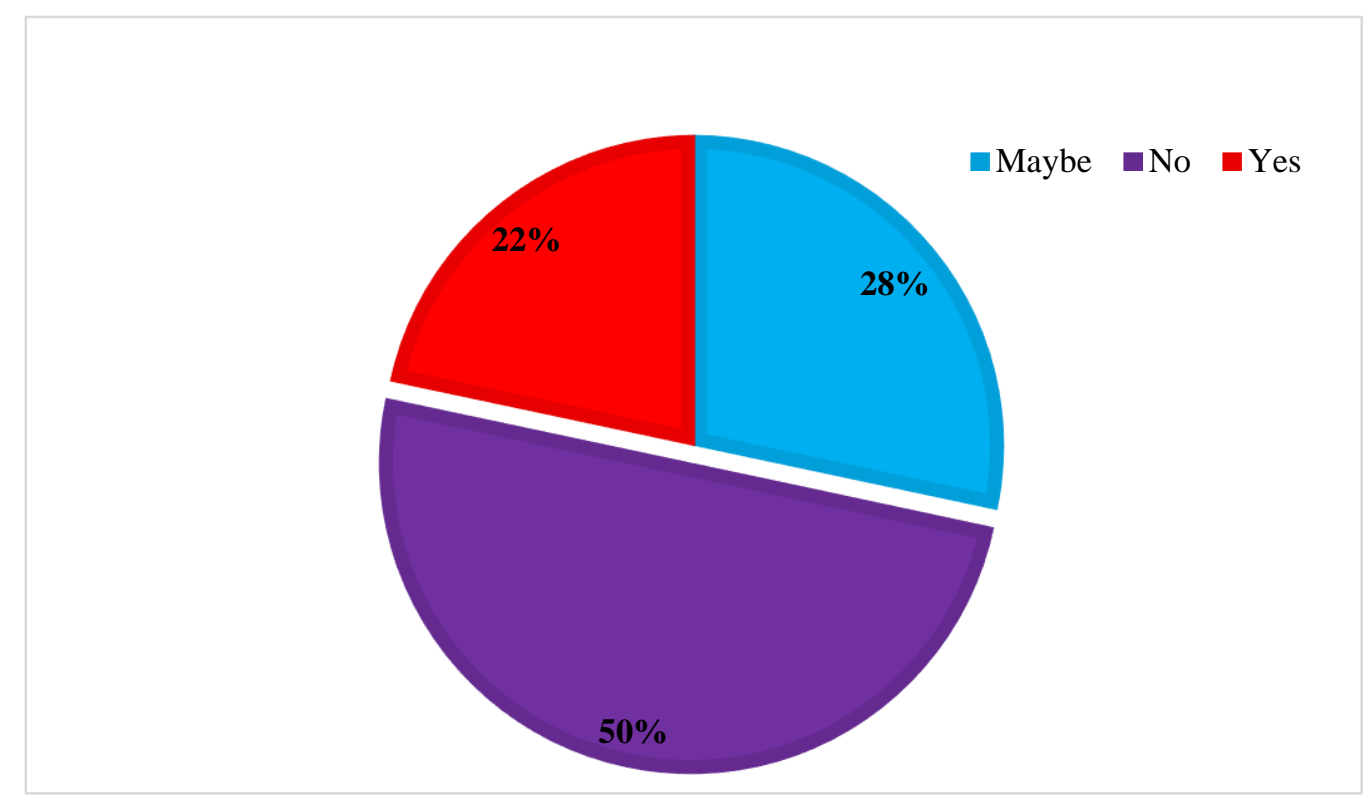

Figure 12. Preference for genetically modified foods (source: author's construct, 2019).

\section{Conclusions}

The complex change system of urban areas coupled with the poor resource distribution among women reflects a challenging way of monitoring the efficiency of land use and food access in communities. Agriculture or food access could be a luxury in urban communities in Ghana. Although most women in Accra originate from rural areas, it is unreliable to predict that their only motivation for farming and food trading stems from their inability to enter into other urban livelihoods. Rather, this research evidently suggests that women farmers and food traders have personal stakes in this urban phenomenon particularly due to the land access disparities. Despite their restrictions to land access and ownership, they have still managed to contribute immensely towards the availability and distribution of food. Consequently, GIS-based urban growth modelling can provide measurable and visualized methods for determining spatial and nonspatial information. It provides the leveraging tool of importing indicators for the systematic monitoring and predictions of issues in cities. Women in urban communities like Adenta have various social, economic and political limitations as far as acquiring land properties and supporting food efficiency is concerned. In this study, the local women interviewed had various educational backgrounds, formal and informal experience, and diverse 
limited processes for entering the land market. These processes evaluated previously held notions that construct women and informal workers to be poor, uneducated and unemployed. However, it was also noticed that women engaged in power structures on a daily basis that both benefit them and burden them, depending on their socio-economic status and other factors.

This study identified the plurality of land and food systems in urban districts. It is followed with the impact of urban changes on land and food demand and its accessibility in the urban regions of Ghana. It concluded on the importance of modelling land and food disparities in Adenta which is characterized by high population growth, destruction of vegetative and agricultural lands for development, among others. Ghana's urban districts need to embrace the package of tools and methodologies in numerical modelling and simulation capacities to review cities and municipalities as multidimensional, socio-ecological systems that have an evolving character in order to appreciate gender-based functionalities. Exploring these urban pointers was systematically and seamlessly allowed for ranking and prioritization of the land and food components that needed more attention, with women not being disregarded. Whilst urban growth, economic and social changes were influencers on urban land and food disparity index, the economic access indicator had weights closer to the urban food stress index. This meant that initiating policies to empower women economically could facilitate their chances of acquiring lands and becoming independent.

Author Contributions: Conceptualization, K.O.T., K.A., J.A., and C.Y.A.; Data curation, K.O.T.; Formal analysis, K.O.T. and K.A.; Investigation, K.O.T. and K.A.; Methodology, K.O.T.; Supervision, K.A., J.A., and C.Y.A.; Validation, K.A., J.A., and C.Y.A.; Visualization, K.O.T., and K.A.; Writing-original draft, K.O.T. and K.A.; Writing-review \& editing, K.O.T., K.A., J.A., and C.Y.A. All authors have read and agreed to the published version of the manuscript.

Funding: The publication of this article was funded by the Open Access Fund of Leibniz Universität Hannover.

Acknowledgments: The data used in this study were curated as part of the MPhil. studies of K.T. under a DAAD In-Country/In-Region Programme NELGA Research Fellowship (2019). Further analysis was solely based on the research interests of the authors without any funding.

Conflicts of Interest: The authors declare no conflict of interest.

\section{References}

1. Farvacque-Vitkovic, C.; Raghunath, M.; Eghoff, C.; Boakye, C. Development of the Cities of Ghana: Challenges, Priorities and Tools; Africa Region Working Paper Series; The World Bank: Washington, DC, USA, 2008.

2. Anand, S.; Jagadeesh, K.; Adelina, C.; Koduganti, J. Urban food insecurity and its determinants: A baseline study of Bengaluru. Environ. Urban. 2019, 31, 421-442. [CrossRef]

3. Tefft, J.; Jonasova, M.; Adjao, R.; Morgan, A. Food Systems for an Urbanizing World—Knowledge Product; The World Bank: Washington, DC, USA, 2017.

4. Oduro, C.Y.; Adamtey, R. The Vulnerability of Peri-Urban Farm Households with the Emergence of Land Markets In Accra. J. Sci. Technol. 2017, 37, 85-100.

5. United Nations UN. Transforming our World: The 2030 Agenda for Sustainable Development; Division for Sustainable Development Goals: New York, NY, USA, 2015.

6. New Urban Agenda-Habitat III. Available online: https://habitat3.org/the-new-urban-agenda/ (accessed on 15 October 2020).

7. Ghana Statistical Service (GSS). Population and Housing Census; Ghana Statistical Service (GSS): Accra, Ghana, 2012.

8. Kuusaana, E.D.; Kidido, J.K.; Halidu-Adam, E. Customary Land Ownership and Gender Disparity, Evidence from the Wa Municipality of Ghana. Ghana J. Dev. Stud. 2013, 10, 63-80. [CrossRef]

9. Rünger, M. Governance, Land Rights and Access to Land in Ghana-A Development Perspective on Gender Equity. In Proceedings of the 5th FIG Regional Conference, Marrakech, Morocco, 18-22 May 2011; FIG: Accra, Ghana, 2011.

10. Asiama, S.O. Crossing the Barrier of Time. The Asante Woman in Urban Land Development. Afr. Riv. Trimest. di Stud. e Doc. Dell'istituto Ital. per l'Africa e l'Oriente 1997, 52, 212-236. 
11. Lambrecht, I.B. As a Husband I Will Love, Lead, and Provide. Gendered Access to Land in Ghana. World Dev. 2016, 88, 188-200. [CrossRef]

12. Dery, I. Access to and Control over Land as Gendered: Contextualising Women's Access and Ownership Rights of Land in Rural Ghana. Africanus 2015, 45, 28-48. [CrossRef]

13. USAID. Gender Analysis Report; USAID: Washington, DC, USA, 2020.

14. Arko-Adjei, A. Adapting Land Administration to the Institutional Framework of Customary Tenure. Ph.D. Thesis, Delft University of Technology, Delft, The Netherlands, 2011.

15. Kalabamu, F.T. Divergent paths: Customary land tenure changes in Greater Gaborone, Botswana. Habitat Int. 2014, 44, 474-481. [CrossRef]

16. Ubink, J.M.; Quan, J.F. How to combine tradition and modernity? Regulating customary land management in Ghana. Land Use Policy 2008, 25, 198-213. [CrossRef]

17. Abdulai, R.T.; Ndekugri, I.E. Customary landholding institutions and housing development in urban centres of Ghana: Case Studies of Kumasi and Wa. Habitat Int. 2007, 31, 257-267. [CrossRef]

18. Kuusaana, E.D.; Eledi, J.A. Customary land allocation, urbanization and land use planning in Ghana: Implications for food systems in the Wa Municipality. Land Use Policy 2015, 48, 454-466. [CrossRef]

19. Namubiru-Mwaura, E. Land Tenure and Gender: Approaches and Challenges for Strengthening Rural Women's Land Rights; Women's Voice, Agency, \& Participation Research Series; World Bank Group: Washington, DC, USA, 2014.

20. Acheampong, R.A. Urbanization and Settlement Growth Management. 2019, pp. 171-203. Available online: https://link.springer.com/chapter/10.1007/978-3-030-02011-8_9 (accessed on 10 October 2020).

21. Twum-Baah, K.A. Population growth of Mega-Accra-Emerging issues. In Visions of the City: Accra in the 21st Century; Mills-Tettey, R., Adi-Dako, K., Eds.; Woeli Publishing Services: Accra, Ghana, 2000.

22. Higgins, T.; Fenrich, J. Legal Pluralism, Gender, and Access to Land in Ghana. Forham Environ. Law Rev. 2012, 23, 7-12.

23. Kasanga, K.R.; Kotey, N.A. Land Management in Ghana: Building on Tradition and Modernity; IIED: London, UK, 2001.

24. Mireku, K.O.; Kuusaana, E.D.; Kidido, J.K. Legal implications of allocation papers in land transactions in Ghana-A case study of the Kumasi traditional area. Land Use Policy 2016, 50, 148-155. [CrossRef]

25. Asiama, K.O.; Bennett, R.M.; Zevenbergen, J.A. Participatory Land Administration on Customary Lands: A Practical VGI Experiment in Nanton, Ghana. ISPRS Int. J. Geo-Inf. 2017, 6, 186. [CrossRef]

26. Alden Wily, L. Custom and commonage in Africa rethinking the orthodoxies. Land Use Policy 2008, 25, 43-52. [CrossRef]

27. Magigi, W.; Drescher, A.W. The dynamics of land use change and tenure systems in Sub-Saharan Africa cities; learning from Himo community protest, conflict and interest in urban planning practice in Tanzania. Habitat Int. 2010, 34, 154-164. [CrossRef]

28. Jat, M.K.; Garg, P.K.; Khare, D. Monitoring and modelling of urban sprawl using remote sensing and GIS techniques. Int. J. Appl. Earth Obs. Geoinf. 2008, 10, 26-43. [CrossRef]

29. Bhanjee, S.; Zhang, C.H. Mapping Latest Patterns of Urban Sprawl in Dar es Salaam, Tanzania. Pap. Appl. Geogr. 2018, 4, 292-304. [CrossRef]

30. Bowyer, D. Measuring Urban Growth, Urban Form and Accessibility as Indicators of Urban Sprawl in Hamilton, New Zealand. Master's Thesis, Lund University, Lund, Sweden, 2015.

31. Twum, K.O.; Ayer, J. Connecting the complex dots: A review of urban change complexities in Ghana. Cogent Soc. Sci. 2019, 5, 1677119. [CrossRef]

32. Appiah, J.A. Gender Differences in Access to, and Use of, Farmlands: A Case Study of Abokobi in the Ga East Municipality. Ph.D. Thesis, University of Ghana, Accra, Ghana, 2015.

33. Danso, G.; Cofie, O.; Annang, L.; Obuobie, E.; Keraita, B. Gender and Urban Agriculture: The Case of Accra, Ghana; Resource Centre on Urban Agriculture and Forestry: Accra, Ghana, 2004.

34. Asiama, K.O.; Lengoiboni, M.; van der Molen, P. In the Land of the Dammed: Assessing Governance in Resettlement of Ghana's Bui Dam Project. Land 2017, 6, 80. [CrossRef]

35. Kalabamu, F.T. Patriarchy and women's land rights in Botswana. Land Use Policy 2006, 23, 237-246. [CrossRef]

36. Yngstrom, I. Women, Wives and Land Rights in Africa: Situating Gender Beyond the Household in the Debate Over Land Policy and Changing Tenure Systems. Oxf. Dev. Stud. 2002, 30, 21-40. 
37. Knox, A.; Duvvury, N.; Milici, N. Connecting Rights to Reality: A Progressive Framework of Core Legal Protections for Women's Property Rights; International Center for Research on Women (ICRW): Washington, DC, USA, 2007.

38. Pinstrup-Andersen, P. Food security: Definition and measurement. Food Secur. 2009, 1, 5-7.

39. van der Molen, P. Food security, land use and land surveyors. Surv. Rev. 2017, 49, 147-152.

40. WFP. World Hunger Series: Hunger and Markets; World Food Programme: Rome, Italy, 2009.

41. Rockson, G.; Bennett, R.; Groenendijk, L. Land administration for food security: A research synthesis. Land Use Policy 2013, 32, 337-342.

42. Crush, J.S.; Frayne, G.B. Urban food insecurity and the new international food security agenda. Dev. South. Afr. 2011, 28, 527-544.

43. Crush, J.; Caesar, M. City without choice: Urban food insecurity in Msunduzi, South Africa. Urban Forum 2014, 26, 165-175.

44. Chen, S.; Ravallion, M. The Developing World Is Poorer Than We Thought, But No Less Successful in the Fight against Poverty; The World Bank: Washington, DC, USA, 2008.

45. Lacey, E.J. Understanding The Livelihoods Of Women In The Local Foodscape: A Case Study of Accra, Ghana. Master' Thesis, University of Oregon, Eugene, Oregon, 2010.

46. Agana, C. Women's Land Rights and Access to Credit in a Predominantly Patrilineal System of Inheritance: Case Study of The Frafra Traditional Area, Upper East Region. Ph.D. Thesis, KNUST, Kumasi, Ghana, 2012.

47. Simon, D.; McGregor, D.; Thompson, D. The search for peri-urban resources sustainability. In The PeriUrban Interface: Approaches to Sustainable Natural and Human Resource Use; Simon, D., McGregor, D., Thompson, D., Eds.; Sinica: London, UK, 2006; pp. 1-17.

48. Adentan Municipal Assembly. Medium Term Development Report. Adenta, Ghana. 2017. Available online: https://new-ndpc-static1.s3.amazonaws.com/CACHES/PUBLICATIONS/2016/04/04/GR_Adentan+ Municipal_2014-2017+MTDP.pdf (accessed on 31 October 2020).

49. Acheampong, R.A. Spatial Planning in Ghana; The Urban Book Series; Springer: Cham, Switzerland, 2019; ISBN 978-3-030-02010-1.

50. COHRE. Bringing Equality Home: Promoting and Protecting the Inheritance Rights of Women: A Survey of Law and Practice in Sub-Saharan Africa; Centre on Housing Rights and Evictions: Geneva, Switzerland, 2004.

51. Capaldo, J.; Karfakis, P.; Knowles, M.; Smulders, M. A model of vulnerability to food insecurity. 2010. [CrossRef]

52. FAO. Regional Overview of Food Security and Nutrition in Africa 2017; FAO: Rome, Italy, 2017.

53. Torvikey, G.D. Strengthening Women's Voices in the Context of Agricultural Investments: Lessons from Ghana. Accra/London. 2016. Available online: https://pubs.iied.org/pdfs/12591IIED.pdf (accessed on 10 October 2020).

54. Saaty, T.L. A scaling method for priorities in hierarchical structures. J. Math. Psychol. 1977, 15, $234-281$.

55. Saran, S.; Ramana, K.V. Site Suitability Analysis for Industries Using Gis and Multi Criteria Decision Making. ISPRS Ann. Photogramm. Remote Sens. Spat. Inf. Sci. 2018, IV-5, 447-454.

56. Hagai, M. Food Security Modeling Using Geographic Information Systems (GIS) Techniques: A Strategy Towards Reliable Food Security Information \& Early Warning Systems (FSIEWS) for Tanzania. J. L. Adm. East. Afr. 2014, 2, 130945610.

57. Darfour, B.; Rosentrater, K.A. Agriculture and Food Security in Ghana. In Proceedings of the 2016 ASABE International Meeting, Orlando, FL, USA, 17-20 July 2016; American Society of Agricultural and Biological Engineers: St. Joseph, MI, USA, 2016.

58. FAO, R. and W.B. Urban Food Systems Diagnostic and Metrics Framework, Roadmap for Future Geospatial and Big Data Analytics; World Bank: Washington, DC, USA, 2017.

59. GSS. Ghana Living Standards Survey (GLSS6). 2012. Available online: https://www.ilo.org/surveyLib/index. $\mathrm{php} / \mathrm{catalog} / 466 /$ stuady-description (accessed on 10 October 2020).

60. Dubbeling, M.; Renting, H.; Hoekstra, F.; Wiskerke, J.S.C.; Carey, J. City Region Food Systems. Urban Agriculture Magazine, 29 May 2015.

61. Potere, D.; Schneider, A. A critical look at representations of urban areas in global maps. GeoJournal 2007, 69, 55-80. [CrossRef]

62. The World Bank. Urban Agriculture, Findings from Four City Case studies; The World Bank: Washington, DC, USA, 2013. 
63. FAO. Rome Declaration on World Food Security; FAO: Rome, Italy, 1996.

64. United Nations. Open Working Group Proposal for Sustainable Development Goals; United Nations: New York, NY, USA, 2015.

65. Yankson, P.W.K. Urbanisation Industrialisation and National Development: Challenges and Prospects of Economic Reform and Globalisation; Ghana Universities Press: Accra, Ghana, 2006.

Publisher's Note: MDPI stays neutral with regard to jurisdictional claims in published maps and institutional affiliations.

(C) 2020 by the authors. Licensee MDPI, Basel, Switzerland. This article is an open access article distributed under the terms and conditions of the Creative Commons Attribution (CC BY) license (http://creativecommons.org/licenses/by/4.0/). 